\title{
Pittosporum mackeei
}

\author{
Assessment by: Gemmill, C., Veillon, J.-M., Amice, R., Cazé, H., Dumontet, V., \\ Fleurot, D., Garnier, D., Gâteblé, G. \& Maggia, L.
}

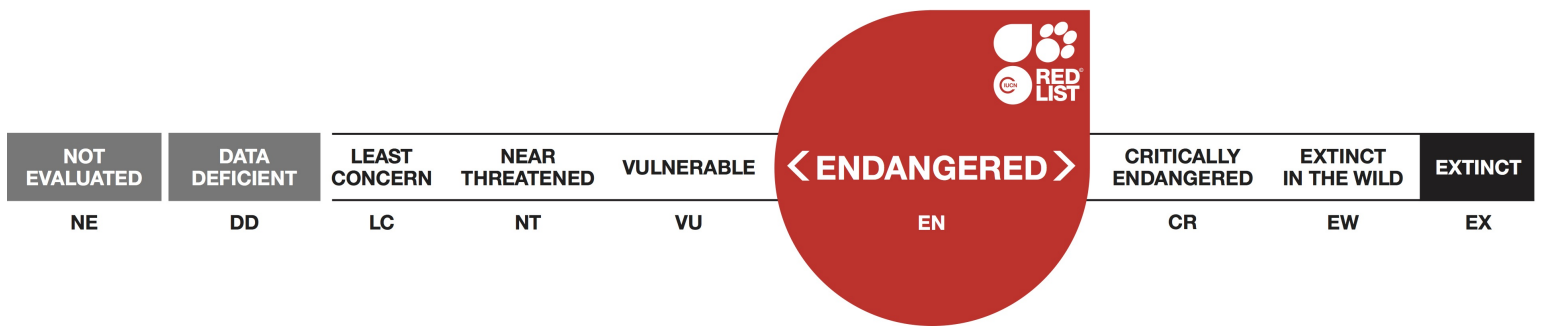

View on www.iucnredlist.org

Citation: Gemmill, C., Veillon, J.-M., Amice, R., Cazé, H., Dumontet, V., Fleurot, D., Garnier, D., Gâteblé, G. \& Maggia, L. 2017. Pittosporum mackeei. The IUCN Red List of Threatened Species 2017: e.T82948039A82951847. http://dx.doi.org/10.2305/IUCN.UK.20173.RLTS.T82948039A82951847.en

Copyright: (C) 2017 International Union for Conservation of Nature and Natural Resources

Reproduction of this publication for educational or other non-commercial purposes is authorized without prior written permission from the copyright holder provided the source is fully acknowledged.

Reproduction of this publication for resale, reposting or other commercial purposes is prohibited without prior written permission from the copyright holder. For further details see Terms of Use.

The IUCN Red List of Threatened Species ${ }^{T M}$ is produced and managed by the IUCN Global Species Programme, the IUCN Species Survival Commission (SSC) and The IUCN Red List Partnership. The IUCN Red List Partners are: Arizona State University; BirdLife International; Botanic Gardens Conservation International; Conservation International; NatureServe; Royal Botanic Gardens, Kew; Sapienza University of Rome; Texas A\&M University; and Zoological Society of London. 


\section{Taxonomy}

\begin{tabular}{|c|c|c|c|c|}
\hline Kingdom & Phylum & Class & Order & Family \\
\hline Plantae & Tracheophyta & Magnoliopsida & Rosales & Pittosporaceae \\
\hline
\end{tabular}

Taxon Name: Pittosporum mackeei Tirel \& Veillon

\section{Taxonomic Source(s):}

Tirel, Ch. and Veillon, J.-M. 2002. Flore de la Nouvelle-Calédonie, tome 24. Pittosporaceae. Museum d'Histoire Naturelle, Paris.

\section{Assessment Information}

Red List Category \& Criteria: $\quad$ Endangered B1ab(iii)+2ab(iii) ver 3.1

Year Published: 2017

Date Assessed: July 23, 2015

\section{Justification:}

Pittosporum mackeei is an uncommon endemic small tree, occurring exclusively in Ponérihouen area at an altitudinal range 100-500 m asl. Its area of occupancy is equal to $20 \mathrm{~km}^{2}$ and its extent of occurrence to $428 \mathrm{~km}^{2}$ and has a total of five subpopulations (=locations) which are all threatened by Rusa Deer (Rusa timorensis). Rusa Deer is an invasive species completely adapted to New Caledonian ecosystems, and is the cause of the continuous decline in habitat quality of $P$. mackeei and other native and endemic plant species of humid forests. Using criterion B, P. mackeei qualifies for listing as Endangered (EN) B1ab(iii)+2ab(iii).

\section{Geographic Range}

\section{Range Description:}

Pittosporum mackeei is an uncommon endemic small tree from New Caledonia, occurring exclusively in the centre part of Grande Terre in Ponérihouen area.

\section{Country Occurrence:}

Native: New Caledonia 


\section{Distribution Map}

\section{Pittosporum mackeei}

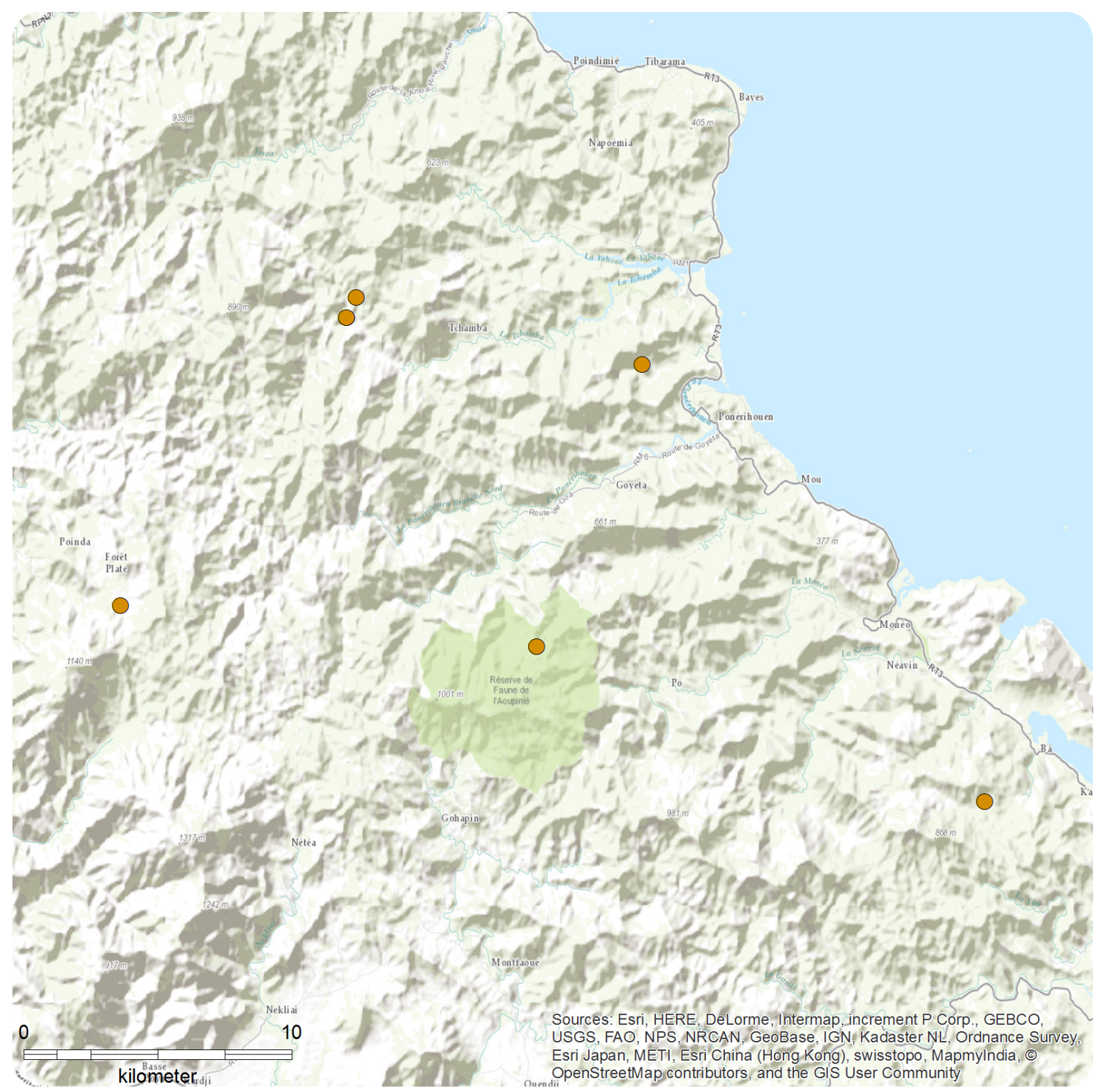

Range

Extant (resident)
Compiled by:

IUCN SSC New Caledonia Plants RLA

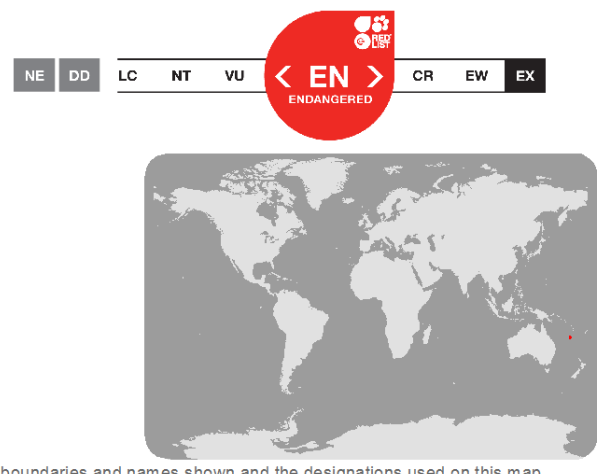

The boundaries and names shown and the designations used on this $m$ ap 


\section{Population}

Population size is unknown. Observed individuals are usually isolated plants.

Current Population Trend: Decreasing

\section{Habitat and Ecology (see Appendix for additional information)}

Pittosporum mackeei is a species present in dense humid forest on schist, greywackes and occasionally on calcareous soils (height of Nato).

Systems: Terrestrial

\section{Threats (see Appendix for additional information)}

The main threat comes from Rusa Deer (Rusa timorensis), which were introduced in New Caledonia in the 1880s. This invasive species is now perfectly adapted to New Caledonian habitats and is affecting native plants directly (killing plants by eating bark and seedlings) and indirectly (through habitat degradation).

\section{Conservation Actions (see Appendix for additional information)}

Unprotected by legislation, Pittosporum mackeei is, however, known from réserve de nature sauvage du massif de l’Aoupinié.

\section{Credits}

Assessor(s): $\quad$ Gemmill, C., Veillon, J.-M., Amice, R., Cazé, H., Dumontet, V., Fleurot, D., Garnier, D., Gâteblé, G. \& Maggia, L.

Reviewer(s): $\quad$ Tanguy, V.

Facilitators(s) and Chanfreau, S.

Compiler(s): 


\section{Bibliography}

Endemia.nc. 2016. Faune et Flore de Nouvelle-Calédonie. Available at: http://www.endemia.nc.

IUCN. 2017. The IUCN Red List of Threatened Species. Version 2017-3. Available at: www.iucnredlist.org. (Accessed: 7 December 2017).

Tirel, Ch. and Veillon, J.-M. 2002. Flore de la Nouvelle-Calédonie, tome 24. Pittosporaceae. Museum d'Histoire Naturelle, Paris.

\section{Citation}

Gemmill, C., Veillon, J.-M., Amice, R., Cazé, H., Dumontet, V., Fleurot, D., Garnier, D., Gâteblé, G. \& Maggia, L. 2017. Pittosporum mackeei. The IUCN Red List of Threatened Species 2017: e.T82948039A82951847. http://dx.doi.org/10.2305/IUCN.UK.2017-3.RLTS.T82948039A82951847.en

\section{Disclaimer}

To make use of this information, please check the Terms of Use.

\section{External Resources}

For Images and External Links to Additional Information, please see the Red List website. 


\section{Appendix}

\section{Habitats}

(http://www.iucnredlist.org/technical-documents/classification-schemes)

\begin{tabular}{|c|c|c|c|}
\hline Habitat & Season & Suitability & $\begin{array}{l}\text { Major } \\
\text { Importance? }\end{array}$ \\
\hline 1. Forest $->$ 1.6. Forest - Subtropical/Tropical Moist Lowland & - & Suitable & - \\
\hline 3. Shrubland -> 3.5. Shrubland - Subtropical/Tropical Dry & - & Suitable & - \\
\hline
\end{tabular}

\section{Threats}

(http://www.iucnredlist.org/technical-documents/classification-schemes)

\begin{tabular}{|c|c|c|c|c|}
\hline Threat & Timing & Scope & Severity & Impact Score \\
\hline \multirow{5}{*}{$\begin{array}{l}\text { 8. Invasive and other problematic species, genes \& } \\
\text { diseases }->8.1 \text {. Invasive non-native/alien } \\
\text { species/diseases }->8.1 .2 \text {. Named species (Rusa } \\
\text { timorensis) }\end{array}$} & Ongoing & - & - & - \\
\hline & Stresses: & \multirow{4}{*}{\multicolumn{3}{|c|}{$\begin{array}{l}\text { 1. Ecosystem stresses }->1.2 \text {. Ecosystem degradation } \\
\text { 2. Species Stresses }->\text { 2.1. Species mortality } \\
\text { 2. Species Stresses }->\text { 2.2. Species disturbance } \\
\text { 2. Species Stresses }->2.3 \text {. Indirect species effects }-> \\
\text { 2.3.7. Reduced reproductive success }\end{array}$}} \\
\hline & & & & \\
\hline & & & & \\
\hline & & & & \\
\hline
\end{tabular}

\section{Conservation Actions in Place}

(http://www.iucnredlist.org/technical-documents/classification-schemes)

\begin{tabular}{|l|}
\hline Conservation Actions in Place \\
\hline In-Place Land/Water Protection and Management \\
\hline Occur in at least one PA: Yes \\
\hline Invasive species control or prevention: No \\
\hline In-Place Species Management \\
\hline Successfully reintroduced or introduced beningly: No \\
\hline Subject to ex-situ conservation: No \\
\hline
\end{tabular}

\section{Additional Data Fields}

\section{Distribution}

Estimated area of occupancy (AOO) $\left(\mathrm{km}^{2}\right): 20$

Continuing decline in area of occupancy (AOO): No 


\section{Distribution}

Extreme fluctuations in area of occupancy (AOO): No

Estimated extent of occurrence (EOO) $\left(\mathrm{km}^{2}\right): 428$

Continuing decline in extent of occurrence (EOO): No

Extreme fluctuations in extent of occurrence (EOO): No

Number of Locations: 5

Continuing decline in number of locations: No

Extreme fluctuations in the number of locations: No

Lower elevation limit (m): 100

Upper elevation limit (m): 550

Population

Continuing decline of mature individuals: No

Extreme fluctuations: No

Population severely fragmented: No

No. of subpopulations: 5

Extreme fluctuations in subpopulations: No

Habitats and Ecology

Continuing decline in area, extent and/or quality of habitat: Yes

Generation Length (years): 0 


\section{The IUCN Red List Partnership}

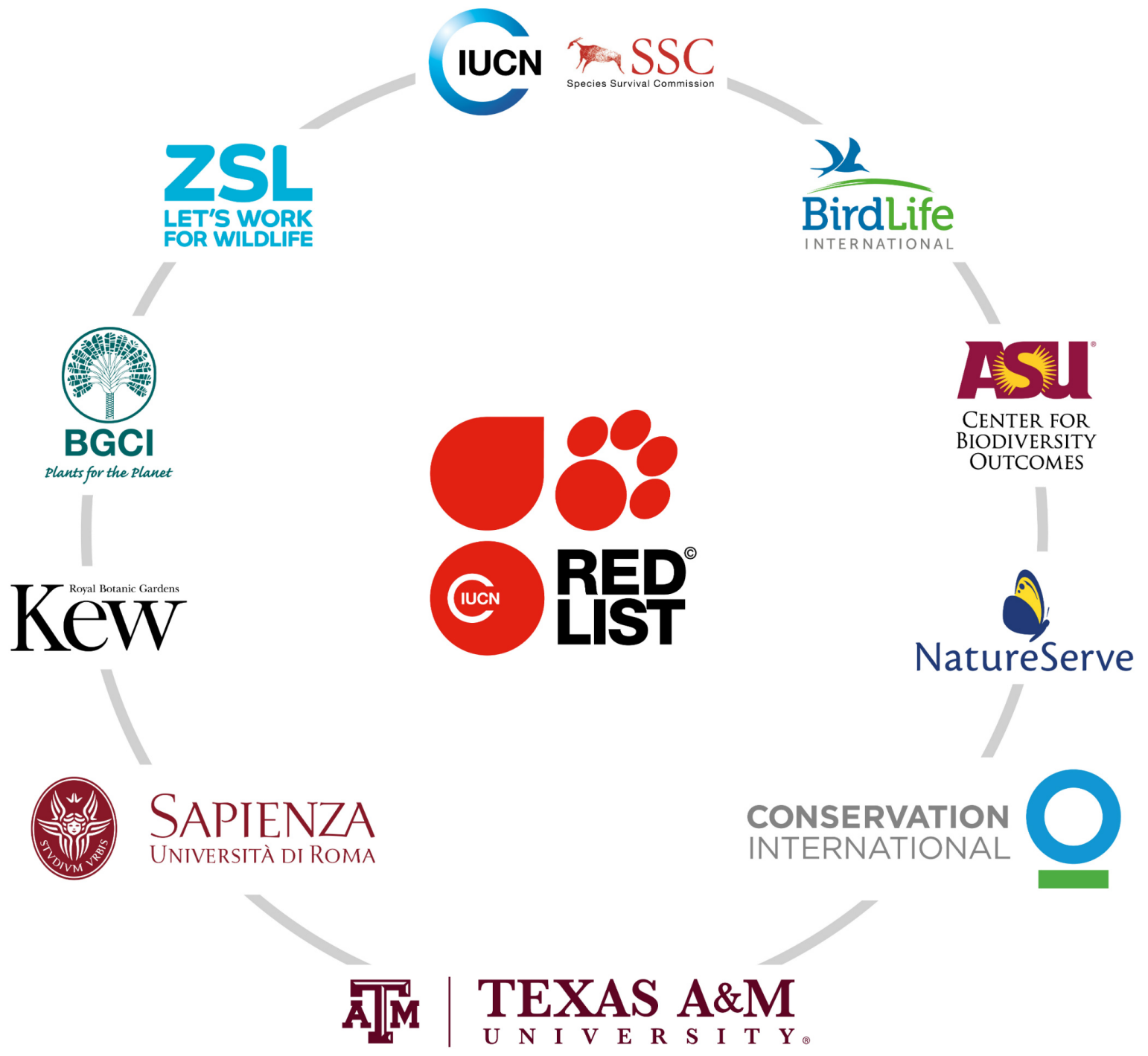

The IUCN Red List of Threatened Species ${ }^{\mathrm{TM}}$ is produced and managed by the IUCN Global Species Programme, the IUCN Species Survival Commission (SSC) and The IUCN Red List Partnership.

The IUCN Red List Partners are: Arizona State University; BirdLife International; Botanic Gardens Conservation International; Conservation International; NatureServe; Royal Botanic Gardens, Kew; Sapienza University of Rome; Texas A\&M University; and Zoological Society of London. 